\title{
Long Intergenic Non-Coding RNA LINC00922 Aggravates the Malignant Phenotype of Breast Cancer by Regulating the microRNA-424-5p/BDNF Axis [Retraction]
}

Yue X, Wang Z. Cancer Manag Res. 2020;12:7539-7552.

The Editor and Publisher of Cancer Management and Research wish to retract the published paper. Concerns were raised over alleged image duplication in Figure 1I with similar images from unrelated articles, specifically:

- Figure 1I, panel MDA-MB-231 si-LINC00922 appears to have been duplicated with similar images in Figure 4B from Li et al, 2019 (https://doi.org/10. 18632/aging.102563) and Figure 5C from Zhang et al, 2020 (https://doi.org/10.2147/CMAR. S269774)
The authors responded to our queries but were unable to provide a satisfactory explanation for the alleged duplication and could not provide satisfactory original data for their study. The Editor advised for the article to be retracted.

Our decision-making was informed by our policy on publishing ethics and integrity and the COPE guidelines on retraction.

The retracted article will remain online to maintain the scholarly record, but it will be digitally watermarked on each page as "Retracted".

\section{Publish your work in this journal}

Cancer Management and Research is an international, peer-reviewed open access journal focusing on cancer research and the optimal use of preventative and integrated treatment interventions to achieve improved outcomes, enhanced survival and quality of life for the cancer patient.

The manuscript management system is completely online and includes a very quick and fair peer-review system, which is all easy to use. Visit http://www.dovepress.com/testimonials.php to read real quotes from published authors. 